\title{
SOSIALISASI DAN PELATIHAN MENGENAI PEMBUKUAN SEDERHANA BAGI PELAKU USAHA MIKRO KECIL DAN MENENGAH DI KECAMATAN KEMILING BANDAR LAMPUNG
}

\author{
Hardini Ariningrum ${ }^{1}$, Apip Alansori ${ }^{2}$ \\ ${ }^{1,2)}$ Program Studi Akuntansi, Fakultas Ekonomi, Universitas Malahayati \\ e-mail: hardini.ariningrum@gmail.com, apipalansori95@gmail.com
}

\begin{abstract}
Abstrak
Usaha Mikro Kecil dan Menengah (UMKM) merupakan salah satu tumpuan perekonomian Indonesia. UMKM telah diakui sangat strategis dan penting tidak hanya bagi pertumbuhan ekonomi, tetapi juga untuk pembagian pendapatan yang merata karena peranannya yang sangat penting. Tetapi hanya sedikit UMKM yang mengalami perkembangan kinerja keuangannya. Hal ini disebabkan karena kurangnya pemahaman dari pelaku usaha terhadap pentingnya pembukuan. Dengan melakukan pembukuan maka akan semakin mudah untuk para pelaku usaha mengambil strategi jitu untuk meningkatkan pendapatan.Pengabdian kepada Masyarakat yang dilakukan adalah untuk melakukan sosialisasi dan pelatihan terhadap UKM di Kecamatan Kemiling yaitu mengenai pembukuan sederhana dalam menciptakan kesejahteraan bagi pelaku usaha. Pengabdian pada Masyarakat ini bertujuan untuk memberikan wawasan pengetahuan mengenai pembukuan sederhana bagi para pelaku usaha di Kecamatan Kemiling Bandar Lampung. Permasalahan utama yang akan dicarikan solusi melalui kegiatan ini meliputi aspek motivasi diri dan pemahaman terhadap keuangan. Kegiatan ini akan dilaksanakan dengan metode ceramah, praktek dan diskusi. Hasil Kegiatan pelatihan menunjukkan tanggapan yang sangat baik dari masyarakat dilihat dari motivasi dari para pelaku usaha untuk membuat pembukuan yang baik dan sistematis demi kemajuan dan kelangsungan usaha tersebut.
\end{abstract}

Kata kunci: Sosialisasi, Pembukuan Sederhana, Pelaku UMKM.

\begin{abstract}
Micro, small and medium enterprises (MSMEs) are one of the foundations of the Indonesian economy. MSMEs have been recognized as very strategic and important not only for economic growth, but also for equitable distribution of income because of their very important role. But only a few MSMEs have experienced developments in their financial performance. This is due to a lack of understanding by business actors on the importance of bookkeeping. By doing bookkeeping, it will be easier for business actors to take accurate strategies to increase income. Community service that is carried out is to conduct socialization and training for SMEs in Kemiling District, namely regarding simple bookkeeping in creating welfare for business actors

This community service aims to provide insightful knowledge about simple bookkeeping for business people in the Kemiling District of Bandar Lampung. The main problems that will be resolved through this activity include aspects of self-motivation and understanding of finances. This activity will be carried out by means of lectures, practices and discussions. The results of the training activities show a very good response from the community as seen from the motivation of business actors to make good and systematic bookkeeping for the progress and continuity of the business.
\end{abstract}

Keywords: Socialization, Simple Bookkeeping, MSME Actors.

\section{PENDAHULUAN}

Usaha mikro kecil dan menengah merupakan salah satu pilar ekonomi kerakyatan untuk mewujudkan pemerataan kesempatan bagi seluruh masyarakat untuk berusaha secara mandiri dalam rangka meningkatkan taraf hidup dan diharapkan dapat mengurangi kesenjangan pendapatan. Keberadaan UMKM yang sangat besar mampu mewakili hampir seluruh unit usaha di berbagai sektor ekonomi yang hidup dalam perekonomian. Di masa krisis usaha mikro kecil dan 
menengah dinilai masih mampu bertahan bahkan mampu berkembang, karena fleksibilitasnya dan ketidak tergantungannya pada pembiayaan melalui kredit perbankan (Widiastuti et al., 2018).

UMKM di Indonesia semakin hari semakin meningkat jumlahnya. Tetapi hanya sedikit UMKM yang mengalami perkembangan kinerja keuangannya. Hal ini disebabkan karena kurangnya pemahaman dari pelaku usaha terhadap pentingnya pembukuan. Dengan melakukan pembukuan maka akan semakin mudah untuk para pelaku usaha mengambil strategi jitu untuk meningkatkan pendapatan. Para pelaku UMKM masih ada yang enggan untuk membuat laporan pembukuan. Padahal setiap perusahaan termasuk skala mikro kecil dan menengah wajib memiliki sistem pembukuan dan laporan keuangan usaha sebagai alat untuk mengukur kinerja. Pengelolaan keuangan pun dapat digunakan sebagai peta dalam membuat keputusan yang tepat untuk memaksimalkan profit, pengaturan arus kas, hingga mengambil perencanaan strategis untuk keberlangsungan usaha yang di jalankan. Hal ini sulit dicapai oleh pelaku usaha yang tidak menerapkan pembukuan/pengelolaan keuanagan karena mereka cenderung tidak mampu memisahkan keuangan pribadi dengan keuangan perusahaan. Kondisi ini membuat pelaku usaha tidak dapat melihat jelas apakah bisnisnya benar-benar menguntungkan (Lubis dan Ovami, 2019).

Banyak pelaku UMKM yang mengelola usahanya tanpa memiliki dasar pengetahuan maupun keterampilan mengenai manajemen usaha dan manajemen keuangan yang baik. Tidak jarang usaha hanya dijalankan dengan mengandalkan insting dan pengalaman saja. Aspek-aspek manajemen usaha yang meliputi perencanaan usaha, pengorganisasian, implementasi, dan pengendalian usaha menjadi sesuatu yang jarang diperhatikan, padahal hal tersebut sangat penting dalam membangun dan mengembangkan usaha. Demikian pula dengan pengelolaan keuangan usaha, banyak UMKM yang tidak melakukan pembukuan formal terhadap usahanya. Perhitungan laba sering dilakukan dengan sederhana tanpa melakukan analisis biaya secara memadai. Misalnya usaha yang menggunakan bahan baku/bahan mentah yang diambil dari lahan sendiri dan melibatkan anggota keluarga sendiri, biasanya tidak memasukkan komponen tersebut sebagai biaya bahan baku dan biaya tenaga kerja dalam penghitungan formal biaya. Semangat berwirausaha yang didukung dengan pengetahuan dan ketrampilan teknis diharapkan akan memberikan bekal dalam memulai dan mengembangkan usaha (Noor et all, 2020).

Sebagian besar pelaku usaha tersebut tidak melakukan pencatatan keuangan dan masih kurang memahami akuntansi dan pelaporan keuangan serta urgensi penggunaannya. Oleh karena itu dinilai perlu untuk membekali mereka dengan pengetahuan tentang akuntansi dan pelaporan. Kalaupun ada pencatatan yang selama ini mereka lakukan, pembukuan UMKM selama ini umumnya sangat sederhana dan cenderung mengabaikan kaidah administrasi keuangan yang standar (Wardiningsih et al., 2020).

Dilihat dari besaran kontribusi UMKM terhadap jumlah unit yang ada, sektor UMKM menjadi wadah untuk pemberdayaan masyarakat. Keterbatasan akses UMKM terhadap sumber pembiayaan formal khususnya perbankan membuat pelaku usaha sulit untuk mengembangkan usahanya, sehingga diperlukan kepedulian institusi maupun lembaga untuk memfasilitasi kebutuhan akan modal tersebut. Untuk memperkuat UMKM, salah satu strategi yang penting adalah kemitraan. Untuk membentuk kemitraan, peran pemerintah dan instansi pendukung lainnya adalah strategis dan penting. Peran pemerintah dapat dilakukan melalui penciptaan iklim usaha yang kondusif untuk menciptakan kemitraan, memberikan fasilitas dan dukungan lain seperti fasilitas penciptaan keserasian (match making), menyediakan bantuan keuangan dan keperluan yang lainnya untuk menjembatani kemitraan antara kedua pihak tersebut. Disamping pemerintah, peran perusahaan besar untuk memberikan suatu dukungan dan menyisihkan sebagian dari keuntungan bersih guna pengembangan UMKM yang dikenal dengan Corporate Sosial Responsibility (CSR) mungkin juga perlu dilanjutkan (Haryani dan Djamil, 2019).

Kegiatan Pengabdian Kepada Masyarakat yang dilakukan dalam bentuk sosialisasi tentang pembukuan sederhana kepada pelaku UMKM di Kecamatan Kemiling Bandar Lampung sebagai mitra pengabdian. Target kegiatan ini adalah menghasilkan jasa yang bisa berupa ilmu pengetahuan tentang cara membuat pembukuan sederhana untuk usaha, yang meliputi ilmu pengetahuan tentang perencanaan pengeluaran keuangan, ilmu pengetahuan tentang pelaksanaan manajemen keuangan, dan ilmu pengetahuan tentang penilaian/pengawasan keuangan UMKM.

Tujuan kegiatan pengabdian kepada masyarakat ini adalah untuk memberikan sosialisasi tentang pembukuan secara sederhana kepada pelaku usaha agar bisa mengelola keuangan supaya 
terhindar dari hutang akibat terlalu banyaknya pengeuaran dalam menjalankan aktivitas sehari-hari. Manfaat dari kegiatan ini bagi mitra pengabdian adalah memberikan pengetahuan tentang cara merencanakan pengeluaran keuangan, pelaksanaan manajemen keuangan dan penilaian/ pengawasan keuangan serta menciptakan kesejahteraan.

Berdasarkan gambaran diatas, maka dapat diambil beberapa permasalahan yang ada pada masyarakat dalam hal ini adalah:

1. keterampilan yang dimiliki masih perlu ditingkatkan untuk menciptakan kesadaran mengenai pentingnya perencanaan keuangan dan pembuatan pembukuan sederhana.

2. Pelaku usaha belum termotivasi akan pentingnya pembukuan bagi usaha mereka.

3. Pelaku usaha belum memahami pembuatan pembukuan yang baik dan sistematis demi kamajuan dan kelangsungan usaha tersebut.

4. Masih rendahnya pengetahuan dan praktek membuat perencanaan keuangan dan pembukuan sederhana bagi pelaku usaha untuk meningkatkan perekonomian dan keuangan usaha.

Setelah mengikuti sosialisasi ini, semua peserta akan dapat termotivasi, disiplin dan komitmen untuk membuat pembukuan, memahami dan meningkatkan keterampilan dalam pembukuan sederhana secara sistematis serta kesadaran para pelaku usaha tentang pentingnya melakukan pembukuan sederhana bagi usaha yang di jalankanya agar bisa ttap bertahan dan bersaing.

\section{METODE}

Metode yang digunakan dalam melaksanakan kegiatan ini adalah dengan melakukan diskusi, sosialisasi dan koordinasi terlebih dahulu pemerintah Kecamatan sebagai penangungjawab mitra yang dilanjutkan dengan rapat terkait pelaksanaan dan sasaran masyarakat di wilayah setempat. Pelaksanaan pada awalnya peserta sosialisasi diberikan pemahaman tentang manfaat dan pentingnya perancanaan keuangan untuk kemajuan usaha.

Peserta sosialisasi berikutnya diberikan penjelasan tentang cara penyusunan laporan keuangan sederhana, kemudian peserta dilatih untuk membuat perencanaan keuangan dengan template atau lembar kerja yang sudah disediakan, sehingga mempermudah dalam pembuatan dan pada akhirnya mampu menghasilkan perencanaan keuangan yang matang dan baik. Rancangan kegiatan pengabdian masyarakat menjadi tiga tahap yaitu:

Tabel 1.

\section{Rencana Kegiatan Pengabdian pada Masyarakat}

\begin{tabular}{|c|c|c|}
\hline TAHAPAN & METODE & HASIL \\
\hline \multirow[t]{3}{*}{ Tahap Awal } & $\begin{array}{l}\text { 1. Tim melakukan survey dan wawancara } \\
\text { langsung dengan Pemerintah Kecamatan } \\
\text { Kemiling Bandar Lampung }\end{array}$ & Gambaran awal demografi UMKM \\
\hline & $\begin{array}{l}\text { 2. Tim melakukan survey dan wawancara } \\
\text { dengan pelaku UMKM }\end{array}$ & Data persentase kelompok UMKM \\
\hline & $\begin{array}{l}\text { 3. Tim melakukan pembuatan modul laporan } \\
\text { Keuangan }\end{array}$ & Modul \\
\hline $\begin{array}{c}\text { Tahap } \\
\text { Pelaksanaan }\end{array}$ & $\begin{array}{l}\text { - Sosialisasi } \\
\text { - Pelaksanaan } \\
\text { - Pelatihan } \\
\text { - Pembuatan laporan keuangan } \\
\text { - Pelatihan motivasi kewirausahaan } \\
\end{array}$ & Pemahaman materi modul \\
\hline $\begin{array}{l}\text { Tahap } \\
\text { Akhir }\end{array}$ & Monitoring UMKM & $\begin{array}{l}\text { UMKM dapat mengaplikasikan } \\
\text { pembukuan/pencatatan keuangan } \\
\text { sederhana }\end{array}$ \\
\hline
\end{tabular}

Metodologi pelaksanaan dalam pengabdian pada masyarakat ini dibagi menjadi 3 (tiga) tahap yaitu tahap awal, tahap pelaksanaan dan tahap akhir. Pada tahap awal dilaksanakan 
observasi, dan wawancara secara langsung dengan para pelaku usaha dan aparat pemerintah setempat, hal ini bertujuan untuk mengetahui gambaran masyarakat setempat dan untuk mengetahui permasalahan/kendala yang dihadapi oleh pelaku usaha.

Tahap kedua adalah tahap pelaksanaan berupa: sosialisasi dan pelatihan pembukuan keuangan sederhana yang dapat diaplikasikan oleh pelaku usaha kecil mikro dan menengah, hal ini bertujuan untuk meningkatkan keterampilan dan pengetahuan mengenai manajemen keuangan usaha agar tidak tercampur antara keuangan keluarga dengan keuangan usaha, melalui pencatatan keuangan pelaku usaha dapat mengetahui perkembangan usahanya.

Tahap yang terakhir adalah tahap monitoring. Pada tahap ini, dilakukan metode coaching, dimana para peserta pelatihan menunjukkan hasil pencatatan keuangannya dengan menceritakan hambatan dan kesulitan yang dihadapi dalam melakukan proses pencatanan. Selain pencatatan keuangan, para peserta pelatihan juga diharapkan membagi rencana strategis us aha dalam jangka waktu menengah untuk menunjukkan inovasi-inovasi yang akan dilakukan yang dapat meningkatkan daya saing usaha.

\section{HASIL DAN PEMBAHASAN}

Sesuai dengan rencana yang telah ditentukan sebelum kegiatan sosialisasi dan pealtihan dilaksanakan, kegiatan pengabdian kepada masyarakat ini diawali dengan kegiatan administratif berupa perijinan, dan undangan peserta. Peserta pelatihan ini merupakan usaha kecil mikro dan menengah yang ada di Kecamatan Kemiling Bandar Lampung. Kegiatan pengabdian masyarakat ini diselenggarakan oleh universitas Malahayati dan bekerjasama dengan Pemerintah Kecamatan Kemiling Bandar Lampung. Peserta dalam kegiatan ini adalah pelaku usaha yang berada dilingkungan Kecamatan dan mewakili dari kelurahan. Pelatihan dilaksanakan selama 1 hari pada tanggal 10 Oktober 2020 yang bertempat diaula Kecamatan Kemiling. Setelah pelatihan dilakukan, pendampingan tetap diberikan selama 1 minggu.

Kegiatan pelatihan yang dilakukan yaitu: penyuluhan pembukuan keuangan sederhana. Pelatihan pembukuan keuangan ini bertujuan untuk meningkatan ketetampilan dan pengatahuan para pelaku usaha, dapat memisahkan keuangan pribadi dengan usaha, serta para pelaku usaha dapat mengetahui perkembangan usahanya melalui pembukuan yang baik. Materi yang disiapkan dalam pelatihan pembukuan keuangan sederhana meliputi:

- Materi pembukuan keuangan sederhana secara umum. Dalam penyampaiannya menjelaskan bahwa pentingnya pembukuan keuangan dalam usaha kecil dan mikro, perlunya memisahkan keuangan pribadi dengan usaha agar pelaku usaha mudah menganalisis hasil usaha.

- Laporan arus kas yang berfungsi menjelaskan tentang jumlah penerimaan dan pengeluaran kas perusahaan dalam satu periode beserta sumber-sumbernya.

- Laporan laba rugi yang berfungsi memberikan informasi tentang aktivitas bisnis perusahaan misalnya Penjualan, Beban, dan Laba atau Rugi Bersih.

- Laporan perubahan modal yang berfungsi menggambarkan peningkatan atau penurunan aktiva bersih atau kekayaan selama periode yang bersangkutan berdasarkan prinsip pengukuran tertentu yang dianut.

- Neraca yang berfungsi menjelaskan nilai Aset, Kewajiban dan Modal perusahaan pada suatu tanggal tertentu.

- Penerapan materi pada soal-soal kasus usaha.

Kegiatan pelatihan ini tidak hanya satu arah, tetapi terjadi dua arah dengan adanya sesi diskusi. Diskusi berlangsung setelah penyampaian materi dengan tertib dan terarah. Pada saat diskusi peserta berperan aktif melakukan tanya jawab terkait dengan permasalahan yang dihadapi oleh pelaku usaha masing-masing. Dampak dan manfaat dari kegiatan pengabdian kepada masyarakat dapat mengelola pembukuan keuangan usahanya dengan baik dan sistematis, sehingga dapat menghasilkan laporan keuangan seusai dengan standar yang berlaku, sehingga dapat membantu kelancaran bantuan dari pihak ketiga (misalnya Bank) yang pada akhirnya dapat membangun kekuatan UMKM sehingga tercapai kesejahteraan masyarakat Indonesia secara adil dan merata. Selain itu, penerapan pembukuan sederhana juga dapat menciptakan budaya disiplin di dalam perusahaan. 


\section{SIMPULAN}

Berdasarkan hasil dan pembahasan yang sudah disampaikan pada pelaksanaan pengabdian masyarakat mengenai sosialisasi dan pelatihan pembukuan sederhana yang ditujukan bagi pelaku UMKM di Kecamatan Kemiling Bandar Lampung, maka dapat diambil kesimpulan sebagai berikut:

1. Pelaksanaan sosialisasi dan pelatihan UMKM di Kecamataan Kemiling berjalan dengan lancar dan aman.

2. Meningkatnya pemahaman keuangan sederhana setelah mengikuti pelatihan, peserta mampu membuat perencanaan keuangan yang bermanfaat dalam mengelola keuangan.

3. Mampu meningkatkan kesadaran peserta pelatihan tentang pentingnya perencanaan keuangan setelah mengikuti pelatihan.

4. Peran Pemerintah Kecamatan Kemiling, Fakultas Ekonomi Universitas Malahayati serta masyarakat membuat acara sosialisasi sukses.

5. Meningkatnya motivasi peserta pelatihan untuk melakukan pembuatan anggaran untuk menabung dan berinvestasi dalam mengelola keuangan.

6. Kerjasama panitia sangat baik.

7. Pelatihan pembukuan sederhana pada pelaku usaha telah berjalan dengan baik dan lancar serta dapat meningkatkan penyusunan dan pengelolaan keuangan sehingga dapat diterapkan praktis dalam mengelola usaha.

\section{SARAN}

1. Kegiatan sosialisasi dan pelatihan bagi pelaku UMKM perlu dilanjutkan karena sangat membantu dalam mengembangkan usahanya.

2. Peserta pelatihan yang berkasnya lengkap diharapkan mendapatkan bantuan kredit dari pihak ketiga.

3. Perlu adanya pemantauan terhadap UMKM supaya tetap berkembang dalam menjalankan usahanya.

4. Diharapkan adanya bantuan dari pihak lain dalam hal mengenai pendanaan untuk keberlangsungan usaha.

5. Kerjasama Pemerintah, khususnya Pemerintah Kecamatan Kemiling dengan Fakultas Ekonomi Universitas Malahayati diharapkan berkelanjutan.

\section{UCAPAN TERIMA KASIH}

Ucapan Terima kasih tak terhingga kami sampaikan kepada Tim Pengabdian pada masyarakat Universita Malahayati Bandar Lampung sehingga kegiatan pengabdian masyarakat internal ini dapat berjalan dengan lancar, Bapak Camat Kemiling beserta jajaran, pelaku UMKM di Kecamatan Kemiling, dan semua kalangan masyarakat yang sudah memfasilitasi dan memberi dukungan penuh kepada kami dalam melaksanakan kegiatan Pengabdian kepada Masyarakat ini.

\section{DAFTAR PUSTAKA}

Haryani dan Djamil. (2019). Penyuluhan Teknik Pembukuan Sederhana Dan Aspek Permodalan Pkbl Bagi Ukm Cluster Tepung Tapioka, Kabupaten Bogor. Jurnal Abdimas, 1, 28-32.

Lubis dan Ovami. (2019). Pembukuan Sederhana Bagi Ibu Rumah Tangga Di Desa Ara Payung Kecamatan Pantai Cermin. Prosiding Seminar Nasional Hasil Pengabdian, 513-516.

Noor et all. (2020). Pelatihan Tentang Pembukuan Sederhana Bagi Pelaku Usaha Kecil Menengah Sebagai Upaya Pembekalan Keterampilan di Desa Tabing Rimbah Kecamatan Mandastana Kabupaten Barito Kuala. Prosiding Hasil-Hasil Pengabdian Kepada Masyarakat.

Wardiningsih, R., Wahyuningsih, B. Y., Sugianto, R., \& Mataram, U. T. (2020). Pelatihan Pembukuan Sederhana Bagi Pelaku Usaha Kecil ( Mikro ) Di Dusun Bore Desa Kopang. Jurnal Pendidikan Dan Ilmu Sosial, 2, 163-172.

Widiastuti, Santoso, \& Anandha. (2018). Model Pembukuan Sederhana Ukm Bakso Semi Modern

Di Wilayah Kota Semarang Simple Bookkeeping Model Smes Semi Modern Claster Bakso In The Semarang City Aprih Santoso Anandha. Jurnal Dinamika Sosial Budaya, 20(1), 16-29. 